\title{
The effects of an L-methionine combination supplement on symptoms of upper respiratory tract infections and perfor- mance in ultramarathon runners before, during and after ultra-endurance exercise
}

\author{
L M Harden (BA Hons (Biokinetics), MSc) ${ }^{1}$ \\ N Neveling (BA Hons (Biokinetics)) ${ }^{2}$ \\ F Rossouw (BA Hons (Biokinetics), MA (Human Movement Studies)) ${ }^{2}$ \\ S J Semple (M Tech (Sport and Exercise Technology)) ${ }^{2}$ \\ F E Marx (B Tech (Sport and Exercise Technology)) ${ }^{2}$ \\ J Rossouw (DSc (Biochemistry)) ${ }^{2}$ \\ G Rogers (PhD) ${ }^{1}$
}

${ }^{1}$ School of Physiology, University of the Witwatersrand, Johannesburg

${ }^{2}$ Department of Sport and Rehabilitation Sciences, Tshwane University of Technology, Pretoria

\begin{abstract}
Objective. To evaluate whether supplementation with an L-methionine combination would reduce the incidence of upper respiratory tract symptoms (URTS) and improve performance in ultramarathon runners.

Design. A double-blind placebo-controlled study.

Setting. Twenty-one ultramarathon runners (17 males, 4 females) preparing for participation in an $87.3 \mathrm{~km}$ ultramarathon.

Interventions. L-methionine combination supplement (Lmethionine, vitamin $B_{6}$, vitamin $B_{12}$, folic acid and magnesium) or placebo containing potato starch.

Main outcome measures. Incidence of URTS was recorded during the runner's preparation for an ultramarathon race (75 days) and recovery from the same (75 days). CD4+, CD8+ cell counts and ratios were measured pre race, immediately post race and 75 days post race. $\mathrm{VO}_{2 \max }$ and endurance fitness (percentage $\mathrm{VO}_{2 \max }$ at $4 \mathrm{mmol}^{-1}$ lactate concentration) were measured during the
\end{abstract}

\section{CORRESPONDENCE:}

\section{Harden}

School of Physiology

University of the Witwatersrand Medical School

7 York Rd

Parktown

2193

Tel: 011-717 2462

Fax: 011-643 2765

E-mail: hardenlm@physiology.wits.ac.za preparation period for the race.

Results. During the preparation period the incidence of URTS was $36 \%$ in the supplement group and $80 \%$ in the placebo group $(p=0.08)$. The incidence of URTS during the 3 weeks post race was $27 \%$ in the supplement group and $40 \%$ in the placebo group $(p=0.65)$. The CD4+/CD8+ cell ratios were not significantly different between groups. Endurance fitness prior to the race and race times were not significantly different.

Conclusions. Although the findings of the current study show that an L-methionine combination supplement did not reduce the incidence of URTS or improve performance in ultramarathon runners, benefits may be found with a more detailed investigation using larger sample sizes and immunosuppressed athletes.

\section{Introduction}

A high incidence of upper respiratory tract infections (URTIs) has been reported in athletes , $79,21,22^{\text {These infections occur }}$ during periods of intense training and after major competitions such as ultramarathon events. ${ }^{28}$ To compete successfully in these ultramarathon events athletes need to train at least daily, and often twice per day, and therefore it is possible that chronic suppression of immune function may result from the cumulative acute post-exercise suppression of each successive exercise bout. ${ }^{14}$ The increase in infection risk after participation in intense exercise provides a model to study the efficacy of agents that may enhance resistance to such infections. ${ }^{19,22}$

A number of studies have investigated the impact of nutritional supplements on immune status and URTIs, with conflicting results being reported. ${ }^{1,18,22}$ However, none have investigated the role of an L-methionine combination supplement (L-methionine, vitamin $B_{6}$, vitamin $B_{12}$, folic acid and 
magnesium) on symptoms of URTIs in athletes. Results from a study investigating the effects of an L-methionine combination supplement in HIV+ patients propose that it slows the rate of decline in CD4+ cell counts and improves the viral load levels after 3 months. ${ }^{32}$ The 5 active substances (L-methionine, vitamin $B_{6}$, vitamin $B_{12}$, folic acid and magnesium) in the supplement participate in the maintenance of glutathione status and have been shown to elevate intracellular glutathione. . $16,31,33^{-1}$

Magnesium is an essential co-factor for the enzyme methionine adenosyl transferase, which forms S-adenosylmethionine (SAM) from L-methionine. ${ }^{16}$ SAM can provide a methyl group to a variety of substances and S-adenosylhomocysteine (SAH) is formed as a product. ${ }^{16} \mathrm{SAH}$ can then form L-homocysteine and adenosine. ${ }^{16}$ Folate and vitamin $\mathrm{B}_{12}$ are essential co-factors for the remethylation of L-homocysteine to L-methionine. SAH can be converted by 3 enzymatic steps (which involve vitamin $B_{6}$ ) to L-cysteine and subsequently to glutathione. ${ }^{16}$ It is glutathione (a major endogenous antioxidant) that has been found to have antiviral activity and to be important as a mediator of normal immune responsiveness. ${ }^{9,11}$ Strenuous exercise has been shown to deplete tissue glutathione content ${ }^{12,13}$ and increase the risk of URTIs. ${ }^{19}$

In addition to studying the effects of antioxidant supplements on immune status and URTIs, a number of studies have also investigated their role in performance. . $3,25,30,34^{2}$ Although several studies have indicated that supplementation with vitamins $E$ and $C$ decreases exercise-induced oxidative stress, there is little evidence that antioxidant supplementation can improve human performance. ${ }^{24}$ However one well-designed study has reported an improvement in muscular endurance following supplementation with $\mathrm{N}$ acetylcysteine (a glutathione precursor) ${ }^{25}$

Therefore, the purpose of this study was to use a doubleblinded, placebo-controlled design to determine firstly whether supplementation with an L-methionine combination supplement would decrease the incidence of symptoms of URTIs in runners during their preparation and recovery from an ultramarathon race, and secondly whether this supplement would impact on their endurance fitness prior to the ultramarathon and ultimately how it would influence their performance in the ultramarathon.

\section{Methods}

\section{Subjects}

Prior to commencement of this study, ethics approval was obtained from the Committee for Research on Human Subjects of the University of the Witwatersrand.

Thirty healthy well-trained, ultramarathon runners (20 males and 10 females) preparing for participation in an 87.3 $\mathrm{km}$ ultramarathon race volunteered to participate in this study after providing informed consent. Runners reported having run on average $5 \pm 3$ (mean \pm SD) ultramarathons, with the best marathon performances averaging $3.17 \pm 0.22$ (mean \pm SD) hours.

Subjects were paired according to $\mathrm{VO}_{2 \max }$ levels, proposed training programmes and gender. Each member of a pair was randomly assigned to either the supplementation (experimental) or placebo group.

During the training period prior to the race 5 subjects withdrew from the study due to orthopaedic injuries while 4 subjects failed to comply with testing procedures and were asked to discontinue with the study. The dropout rate in the current study $(N=9)$ was high but comparable with that reported in other studies $(N=8) \cdot{ }^{22,23}$ The sample was finally fixed at 21 subjects, which included 4 females and 17 males ( $N=11$ supplement and $N=10$ placebo). Of the final 21 subjects, 6 subjects in each group remained paired according to the criteria stated above.

\section{Performance measurements}

The subjects were required to report to the testing laboratory situated at an altitude of $1330 \mathrm{~m}$ with an average barometric pressure of $656 \mathrm{mmHg}$ and a room temperature regulated at $20-22^{\circ} \mathrm{C}$ on day 1 (75 days before the race). All subjects were tested within the same week. The subjects were familiarised with the testing equipment and procedures prior to the commencement of testing. Subjects were asked not to train for 12 hours prior to all the testing, not to train hard $(\leq 70 \%$ of maximal heart rate) on the day before testing and not to consume any food or caffeinated drinks 3 hours prior to testing.

Each subject was asked to run on a motorised treadmill (Quinton Q65 series 90, Quinton Instrument Co., Bothell, WA, USA). Maximal aerobic capacity $\left(\mathrm{VO}_{2 \max }\right)$ was measured using a continuous model adapted from the Astrand protocol. ${ }^{15}$ The criteria for $\mathrm{VO}_{2 \max }$ included subjects obtaining 2 of the following 3 criteria: a plateau in $\mathrm{VO}_{2}$ despite an increase in workload, a respiratory exchange ratio in excess of 1.10 , and blood lactic acid levels $>8 \mathrm{mmol}^{-1} .^{6}$ Oxygen consumption and ventilation were determined using the MedGraphics $\mathrm{CardiO}_{2}$ combined $\mathrm{VO}_{2}$ /ECG exercise system (Medical Graphics Corporation, St. Paul, MN, USA).

The lactate concentration for capillary blood was measured using the Accusport Analyzer (Boehringer Mannheim, $\mathrm{BmbH}$, Mannheim, Germany) and the BM-Lactate test strips. Blood samples were collected during the last $30 \mathrm{~s}$ of each workload during the $\mathrm{VO}_{2 \max }$ test. Capillary blood was obtained by pricking a fingertip with a lancet. On average 5 blood samples were obtained during each $\mathrm{VO}_{2 \max }$ test. Lactate concentrations at each workload were plotted and an exponential curve was fitted using Table Curve 2D (Jandel Scientific Software, San Rafael, CA, USA). The percentage $\mathrm{VO}_{2 \max }$ at $4 \mathrm{mmol}^{-1}$ lactate was calculated and used as a measure of endurance fitness. ${ }^{8,10}$ The above tests were repeated again 14 days before the race. All tests were again performed within 1 week and at the same time of the day as the first testing session.

In addition to endurance fitness, race time (as obtained from official race records) was also used as a measure of performance.

\section{Supplementation}

Supplementation started on day 2 and ended on day 150 of the study. The supplement (Bio Boost) and placebo were supplied by Biomox Pharmaceuticals in capsule form and administered orally. The active ingredients administered in 
the supplement were: L-methionine $405 \mathrm{mg}$, folic acid 0.36 $\mathrm{mg}$, vitamin $\mathrm{B}_{6} 1.575 \mathrm{mg}$, vitamin $\mathrm{B}_{12} 0.01125 \mathrm{mg}$, magnesium $135 \mathrm{mg}$. The placebo contained potato starch (500 mg per day) and no active ingredients. From day 1 to day 7 (first week of the study) and day 76 to day 83 (first week after the race), subjects ingested 3 capsules twice a day $(1215 \mathrm{mg}$ of L-methionine, $1.08 \mathrm{mg}$ folic acid, $4.725 \mathrm{mg}$ vitamin $\mathrm{B}_{6}$, $0.03375 \mathrm{mg}$ vitamin $\mathrm{B}_{12}$ and $405 \mathrm{mg}$ magnesium) on an empty stomach. After these 2 periods (i.e. days $8-75$ and days 84 - 151) subjects were instructed to ingest 2 capsules twice a day $(810 \mathrm{mg} \mathrm{L}$-methionine, $0.72 \mathrm{mg}$ folic acid, 3.15 $\mathrm{mg}$ vitamin $\mathrm{B}_{6}, 0.0225 \mathrm{mg}$ vitamin $\mathrm{B}_{12}$ and $270 \mathrm{mg}$ magnesium) on an empty stomach. This schedule of ingestion was prescribed by the supplier and manufacturer of the product based on trials done on individual patients by the original formulators (unpublished data) and was the same for the 2 groups.

\section{Incidence of upper respiratory tract symp- toms (URTS)}

The incidence of symptoms of URTIs was recorded daily by the subjects in a logbook provided which was based on the questionnaire used in the studies investigating the effect of glutamine or placebo ingestion on the incidence of infections in runners. ${ }^{2}$ The adapted questionnaire was not validated prior to use in this study. Subjects were asked to record all symptoms reported under the headings of cold, cough, sore throat, running nose, sneezing and influenza and for how long the symptoms were present. $^{2}$ A subject was considered to have an illness when he or she reported 3 symptoms for a cold (cough, sore throat, running nose, sneezing) or influenza (fever, aches and pains in joints or muscles, cough, sore throat) such that they did not train or such that they consulted a doctor for treatment. Other illnesses, e.g. diarrhoea and vomiting were not included. The incidence of the symptoms and the duration of the symptoms (number of days the symptoms were present) was calculated. Recordings were controlled monthly with each visit to the laboratory to collect more supplements and telephonically when booking each appointment. The diagnosis was not verified by clinical examination although patients did indicate if they had seen a medical doctor for treatment.

\section{Blood sampling}

CD4+ and CD8+ measurements were taken on day 75 (18 hours pre-race), day 76 (10 min post race) and on day 150 . With each sampling session blood was drawn from a forearm vein into evacuated collection tubes. The blood for the CD4+ and CD8+ measurements was collected in a $4.5 \mathrm{ml}$ vacuette (K3E EDTA K3, Greiner Labortechnik). Following processing, specimens were packed in a refrigerated container and transported to a central laboratory where they were analysed within 18 hours of collection. The proportions of T-cells (CD4+ and CD8+) were measured using flow cytometry (FACSCount, Becton Dickinson, San Jose, USA) which includes the use of fluorescent labelled monoclonal antibodies to cell surface antigens as previously described. ${ }^{26}$ All concentrations were corrected for changes in plasma volume post race. ${ }^{3}$

\section{Training}

All training information (running distance, time and intensity) and injuries were recorded weekly in a standardised training logbook given to the subjects. The training logbooks were adapted from those used in a study investigating the effects of lactate-correlated training on running performance but were not validated prior to use in this study. ${ }^{27}$

\section{Nutrition}

The subject's compliance with capsule use was recorded daily in a logbook given to the subjects. In addition, every 4 weeks subjects were asked to indicate how many capsules were left before they received a new bottle of capsules. Subjects were asked not to take any other vitamin and mineral supplements for the duration of the study. Dietary habits were evaluated from a 24-h dietary recall. As a method of reporting food intake the 24-h dietary recall questionnaire has been validated against weighted 7-day food records. ${ }^{4}$ The dietary recall was completed daily by each subject to ensure that subjects did not change their diets over the duration of the study. Subjects were taught how to keep accurate food records prior to commencement of the study. Nutrient content of each athlete's reported daily dietary intake was assessed (macro and micro nutrients) using a computerised dietary analysis system (Food Fundi Analyzer 2, Professional Penta Medical Systems, Johannesburg, South Africa).

\section{Statistical analysis}

Data are expressed as means \pm standard deviation (SD). The analysis of changes in all blood measurements (CD4+, CD8+ cell counts and ratio) was done using an analysis of variance (ANOVA) procedure for repeated measures to estimate main effects (group or time) and an interaction effect (group $x$ time) followed by a Tukey-Kramer multiple comparisons post-hoc test. For all other dependent variables the unpaired $t$-test was used to test for the significance of the differences between the groups. A Fisher's exact probability test was used to analyse a $2 \times 2$ contingency table for being sick and not being sick (incidence of illness). The level of significance used was $p \leq 0.05$. A post hoc power analysis showed the power for the following statistical tests: repeated measures ANOVA (time effect power $=0.990$, time $\times$ group effect power $=0.153)$; unpaired $t$-tests $\left(\% \mathrm{VO}_{2 \max } @ 4 \mathrm{mmol} .^{-1}\right.$ lactate power $=0.7968$, duration of symptoms power $=$ 0.4264 ) and Fisher's exact test (incidence of illness power $=$ $0.3196)$.

\section{Results}

\section{Physical characteristics}

The physical and performance characteristics of the subjects are given in Table I. There was no significant group differences on any of the parameters measured. It should be noted that based on the race finishing times and $\mathrm{VO}_{2 \max } \mathrm{val}-$ ues the runners would be classified as non-elite, experienced and well-trained runners. ${ }^{20}$ 
TABLE I. Physical and performance characteristics of the subjects*

\begin{tabular}{|c|c|c|c|}
\hline & $\begin{array}{l}\text { Supplement } \\
\text { group }(N=11)\end{array}$ & $\begin{array}{l}\text { Placebo group } \\
(N=10)\end{array}$ & $P$-value \\
\hline Age (years) & $36 \pm 3$ & $35 \pm 8$ & 0.74 \\
\hline Height (m) & $1.73 \pm 0.09$ & $1.75 \pm 0.05$ & 0.67 \\
\hline $\begin{array}{l}\text { Mass }(\mathrm{kg}) \\
\mathrm{VO}_{2 \max }\end{array}$ & $69.5 \pm 10.7$ & $68.9 \pm 8.4$ & 0.89 \\
\hline $\begin{array}{l}\left(\mathrm{ml} . \mathrm{kg}^{-1} \cdot \mathrm{min}^{-1}\right) \\
\text { Best standard } \\
\text { marathon time }\end{array}$ & $58 \pm 8$ & $57 \pm 7$ & 0.78 \\
\hline (hours) & $3.18 \pm 0.25$ & $3.16 \pm 0.20$ & 0.84 \\
\hline $\begin{array}{l}\text { Best Comrades } \\
\text { marathon }(90 \mathrm{~km}) \\
\text { time (hours) }\end{array}$ & $8.37 \pm 1.09$ & $8.27 \pm 1.07$ & 0.83 \\
\hline${ }^{*}$ Values are means $\pm S D$ & & & \\
\hline
\end{tabular}

\section{Incidence of upper respiratory tract symp- toms (URTS)}

The incidence of symptoms of URTIs in both groups during the 75 days of preparation is shown in Table II. During the preparation period the percentage of symptoms of URTIs $(p=0.08)$ and the duration of symptoms per illness incident ( $p=0.13$ ) was not significantly different. The incidence of URTS $(p=0.65)$ and duration of symptoms $(p=0.55)$ during the 3 weeks following the race was not significantly different. During the entire 75 days of recovery from the race the incidence of URTS $(p=1.00)$ and duration of symptoms was also not significantly different $(p=0.66)$.

\section{Training programmes}

There was no significant difference in the total training distance completed in preparation for the race, with the supplement group completing $896 \pm 235 \mathrm{~km}$ and the placebo group $892 \pm 192 \mathrm{~km}$.

\section{Physiological responses}

Aerobic capacity variables monitored during preparation for the race are shown in Table III. The supplement group had a significantly greater percentage $\mathrm{VO}_{2 \max }$ at $4 \mathrm{mmol}^{-1}$ lactate concentration (endurance fitness) than the placebo group 12 - 14 days prior to the start of the race. However the mean change in endurance fitness over the 75-day training period was not significantly different. No significant differences in
Table III. Aerobic capacity variables monitored during preparation for the race

\begin{tabular}{|c|c|c|}
\hline Parameters & April & $\begin{array}{l}\text { June } \\
\text { (12-14 days prior to the race) }\end{array}$ \\
\hline \multicolumn{3}{|c|}{$\mathrm{VO}_{2 \max }\left(\mathrm{ml} \cdot \mathrm{kg}^{-1} \cdot \mathrm{min}^{-1}\right)$} \\
\hline Supplement & $58 \pm 8$ & $59 \pm 7$ \\
\hline Placebo & $57 \pm 7$ & $58 \pm 7$ \\
\hline \multicolumn{3}{|c|}{$\begin{array}{l}\text { Percentage } \mathrm{VO}_{2 \max } \\
\text { at } 4 \text { mmol- }{ }^{-1} \text { lactate } \\
\text { concentration }\end{array}$} \\
\hline Supplement & $86 \pm 4$ & $87 \pm 4^{*}$ \\
\hline Placebo & $84 \pm 5$ & $83 \pm 5$ \\
\hline
\end{tabular}

Values are means $\pm \mathrm{SD} ; N=11$ supplement and $N=10$ placebo subjects.

Difference between absolute values: April $P>0.05$; ${ }^{*}$ June $P<0.05$

Difference between delta values (June - April); $P=0.08$ for percentage $V_{2} O_{\text {max }}$ at $4 \mathrm{mmol}^{-1}$ lactate concentration; $\mathrm{VO}_{2 \max } P=0.84$

race times were found, with the supplement group running $8.45 \pm 1.54$ hours and the placebo group $8.51 \pm 1.08$ hours.

Prior to the start of the race (18 hours) no significant differences were noted in the immune cell subsets (Figs 1 and 2 ).

CD4+ cells decreased significantly in both groups immediately post race (Fig. 1) while the CD8+ cells only decreased significantly in the supplement group immediately post race (Fig. 2). The CD4+/CD8+ ratio did not change significantly immediately post race in both groups or 75 days post race (Fig. 3). No significant differences were noted between the groups for the CD4+, CD8+ cell counts and ratios.

\section{Nutrition}

The subjects were all Caucasian, from the same socio-economic background and no significant differences $(p>0.05)$ between groups were observed for nutrient analysis of food records across all time periods. The average daily energy intake for all was $13600 \pm 4009 \mathrm{~kJ}^{\text {day }}{ }^{-1}$, with carbohydrate, fat and protein respectively comprising $58 \pm 11.5 \%, 24.2 \pm$ $6.3 \%$ and $15.4 \pm 3.5 \%$ of the daily caloric intake.

\section{Discussion}

The essential finding of this study was that 150 days of supplementation with an L-methionine combination had no significant effect on the incidence of URTS and race

TABLE II. Percentage of symptoms of URTIs and duration of symptoms during the study

\begin{tabular}{|c|c|c|c|c|c|c|}
\hline & Subject/group & $\begin{array}{l}\text { Subjects with } \\
\text { symptoms/total group }\end{array}$ & $\begin{array}{l}\% \text { symptoms } \\
\text { of URTIs }\end{array}$ & $\begin{array}{l}\text { P-value } \\
\% \text { symptoms }\end{array}$ & $\begin{array}{l}\text { Mean duration of } \\
\text { symptoms (days) }\end{array}$ & $\begin{array}{l}\text { P-value } \\
\text { mean duration of symptoms }\end{array}$ \\
\hline $\begin{array}{l}\text { Preparation } \\
(0-75 \text { day })\end{array}$ & $\begin{array}{l}\text { Supplement } \\
\text { Placebo }\end{array}$ & $\begin{array}{l}4 / 11 \\
8 / 10\end{array}$ & $\begin{array}{l}36 \\
80\end{array}$ & 0.08 & $\begin{array}{l}3 \pm 1 \\
5 \pm 3\end{array}$ & 0.13 \\
\hline $\begin{array}{l}3 \text { weeks } \\
\text { post-race } \\
\text { ( } 76-97 \text { day) }\end{array}$ & $\begin{array}{l}\text { Supplement } \\
\text { Placebo }\end{array}$ & $\begin{array}{l}3 / 11 \\
4 / 10\end{array}$ & $\begin{array}{l}27 \\
40\end{array}$ & 0.65 & $\begin{array}{l}4 \pm 2 \\
6 \pm 4\end{array}$ & 0.55 \\
\hline $\begin{array}{l}\text { During } \\
\text { recovery } \\
\text { (76 }-150 \text { day) }\end{array}$ & $\begin{array}{l}\text { Supplement } \\
\text { Placebo }\end{array}$ & $\begin{array}{l}6 / 11 \\
6 / 10\end{array}$ & $\begin{array}{l}55 \\
60\end{array}$ & 1.00 & $\begin{array}{l}6 \pm 4 \\
5 \pm 3\end{array}$ & 0.66 \\
\hline
\end{tabular}




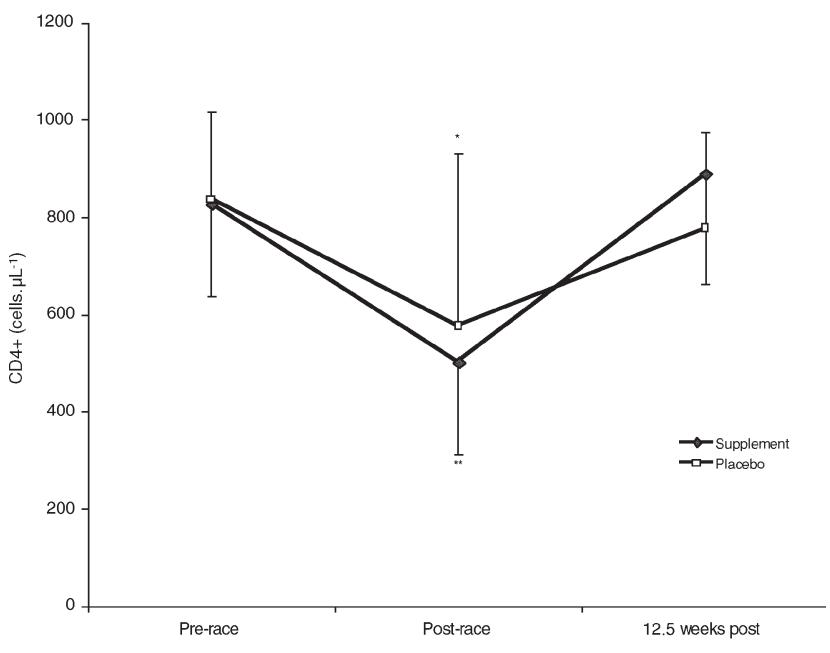

Fig. 1. CD4+ cell measurements in both groups pre-race, immediately post-race and 12.5 weeks post-race $\left({ }^{* *} p<\right.$ 0.001 for the supplement group and * $p<0.001$ for the placebo group immediately post-race when compared with pre-race values). (Values are means $\pm S D ; \mathrm{N}=11$ supplement and $\mathrm{N}=10$ placebo subjects).

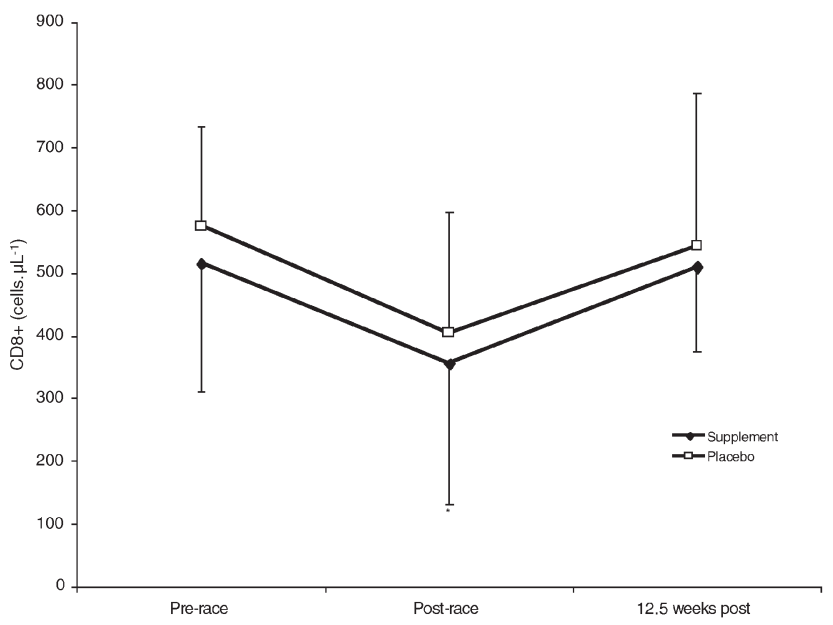

Fig 2. CD8+ cell measurements in both groups pre-race, immediately post-race and 12.5 weeks post-race ${ }^{*} \mathrm{p}<0.01$ for the supplement group immediately post-race when compared with pre-race values). (Values are means \pm SD; $\mathrm{N}=11$ supplement and $\mathrm{N}=10$ placebo subjects).

performance in ultra-endurance runners.

There is evidence for the role of nutrient supplements in modulating the incidence of URTIs post race. Peters et al. ${ }^{22}$ examined the effect of supplementation with vitamin C (an antioxidant) on the URTIs of ultramarathon runners competing in the same race in 1990 and showed that 21 days of vitamin $\mathrm{C}$ supplementation reduced the post-race incidence of URTIs. Glutamine (an amino acid) supplementation immediately post race and 2 hours post race has also been shown to reduce the incidence of infections within 7 days post race in runners competing in marathon and ultramarathon events. $^{2}$

The results of the current study show that supplementation with an L-methionine combination did not influence the

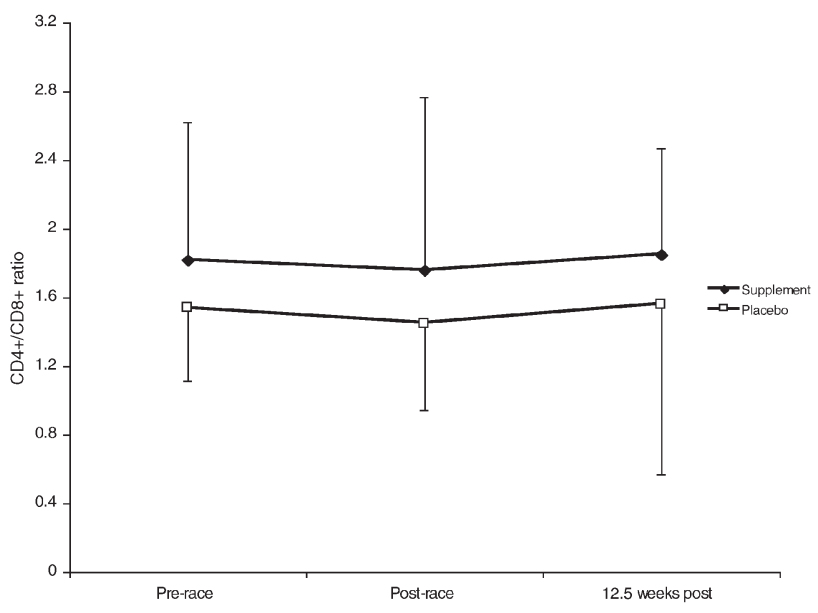

Fig 3. CD4+/CD8+ ratio measurements in both groups prerace, immediately post-race and 12.5 weeks post-race. (Values are means $\pm S D ; N=11$ supplement and $N=10$ placebo subjects).

incidence of URTS during the training for or recovery from an ultramarathon race in runners nor did it reduce the duration of symptoms. One main difference between the above two studies and this study is the use of larger sample sizes (27 88 subjects). Owing to the long duration of the study 9 subjects withdrew, which is similar to what has been reported in other studies. ${ }^{22,23}$ The small sample size used in the current study could influence the acceptance or rejection of the null hypothesis.

In addition to the results on URTS, we did not find any significant differences in the CD4+ and CD8+ cell counts or CD4+/CD8+ cell ratios post race. This immune marker was used as an L-methionine combination supplement (supplement with the same combination as used in this study but at a higher concentration) and $\mathrm{N}$-acetylcysteine (NAC) treatment, both of which are glutathione precursors and have been shown to slow the decrease of CD4+ cell counts in $\mathrm{HIV}+$ patients. ${ }^{12,32}$ The stress of prolonged exhaustive exercise has been shown to lower the CD4+ cell counts and CD4+ to CD8+ cell ratio in athletes. ${ }^{1}$ This marker has also been used in other studies which have examined the effect of supplementation on the immune system post marathon and it has been suggested that a ratio of CD4+/CD8+ cells below 1.5 is below normal and may be a cause of and an indicator of immunosuppression in athletes. ${ }^{17,29}$

There are, however, several factors which might account for the negative findings regarding the immune responses measured in this study. Firstly no CD4+/CD8+ cell measurements were taken during the training period in which the largest difference in the incidence of URTS was noted between the supplement and placebo groups. Secondly, enumeration of circulating cells does not provide as conclusive information on immune function or activation of cells as does examining direct measurements of cell function. ${ }^{35}$ Thirdly, the reported symptoms of URTIs by the subjects were not verified by clinical examination which would have confirmed the presence of an infection. Fourthly, including a non-exercising control group would have strengthened the findings of the current study as the incidence of symptoms in the general population could have been compared with that 
found in the exercising group. Furthermore it has been suggested that the CD4+ T-cell system may be negatively affected not only by suboptimal but also by supraoptimal glutathione levels. ${ }^{12}$ Therefore further investigation is needed to not only analyse the activity of the immune cells in response to L-methionine combination supplementation but also in relation to glutathione levels.

In addition to the role of antioxidant supplements in immune function, previous studies have also examined their effects on performance due to growing evidence indicating that radicals and other reactive oxygen species may contribute to muscular fatigue. ${ }^{24}$ Conflicting results have been presented from these studies which may be due to agent administration, dosage and the pattern of muscular activity used to induce fatigue.

Weight et al. ${ }^{34}$ found that 3 months of vitamin and mineral supplementation had no effect on oxygen consumption, blood lactate turnpoint, peak treadmill running speed and $15 \mathrm{~km}$ time trial performance in 30 well-trained runners. Time to exhaustion at $70 \% \mathrm{VO}_{2 \max }$ was not reduced in 11 highly trained male triathlon athletes after 4 weeks of supplementation with vitamin E, coenzyme Q10, cytochrome C and inosine.$^{30}$ Reid et al.,${ }^{25}$ however found an improvement in muscular endurance (during low frequency stimulation) following treatment with $150 \mathrm{mg} \mathrm{N}$-acetylcysteine (a glutathione precursor). $\mathrm{N}$-acetylcysteine has been shown to increase glutathione levels in plasma and bronchoalveolar lavage fluid in humans; however its use is limited due to a number of side-effects. ${ }^{25}$ In the present study no change in $\mathrm{VO}_{2 \max }$ and endurance fitness (percentage $\mathrm{VO}_{2 \max }$ at $4 \mathrm{mmol}^{-1}$ lactate) was found after 75 days of supplementation. The finding that performance in the race $(87.3 \mathrm{~km})$ was unaltered by supplementation tends to confirm the laboratory findings. These findings are therefore in keeping with the majority of studies showing that long-term supplementation with antioxidant nutrients does not improve human performance. ${ }^{5,24,34}$

\section{Conclusions}

In summary, although the findings of the current study do not support the use of an L-methionine combination supplement in reducing the incidence of URTS in ultramarathon runners, the positive results found with HIV+ patients does suggest that this supplement has a role to play in immune function. Future studies will need to be conducted with larger sample sizes, will need to include measures of immune function and glutathione levels, and will need to be directed at athletes who are shown to be immunosuppressed such as overtrained athletes or patients who present with specific disease states in which glutathione or its precursors are depleted.

\section{Acknowledgements}

We are grateful to the runners who participated in this study, Merc Pharmaceuticals, Biomox Pharmaceuticals and the Faculty of Health Science Medical Research Endowment Fund of the University of the Witwatersrand for financial support. We would like to thank Ungerer Laboratories for their technical assistance, Izak Smit for all his help with the statistical analysis and Professor Lucille Smith for critical advice and careful reading of the manuscript.

\section{References}

1. Castell $L$, Newsholme E. The effects of oral glutamine supplementation on athletes after prolonged, exhaustive exercise. Nutrition 1997; 13: 738-42.

2. Castell L, Poortmans, J, Newsholme, E. Does glutamine have a role in reducing infections in athletes? Eur J Appl Physiol 1996; 73: 488-90.

3. Dill D, Costill, D. Calculation of percentage changes of blood, plasma and red cells in dehydration. J Appl Physiol 1974; 37: 247-8.

4. Edington J, Thorogood M, Geekie M, Ball M, Mann J. Assessment of dietary intake using dietary records with estimated weights. J Hum Nutr Diet 1989; 2: 407-14.

5. Goldfarb AH. Antioxidants: role of supplementation to prevent exerciseinduced oxidative stress. Med Sci Sports Exerc 1993; 25: 232-6.

6. Gore C. Physiological Tests for Elite Athletes. Australian Sports Commission. Champaign, Illinois: Human Kinetics, 2000: 122-3.

7. Heath G, Ford E, Craven T, Macera C, Jackson K, Pate R. Exercise and the incidence of upper respiratory tract infections. Med Sci Sports Exerc 1991; 23: 152-7

8. Heck H, Mader A, Hess G, Mücke R, Müller R, Hollmann W. Justification of the 4-mmol/l lactate threshold. Int J Sports Med 1985; 6: 117-30.

9. Ho WZ, Douglas SD. Glutathione and N-acetylcysteine suppression of human immunodeficiency virus replication in human monocyte/ macrophages in vitro. AIDS Res Hum Retroviruses 1992; 8: 1249-53.

10. Jacobs I. Blood lactate: implications for training and sports performance. Sports Med 1986; 14: 103-8.

11. Kalebic T, Kinter A, Poli G, Anderson ME, Meister A, Fauci AS Suppression of human immunodeficiency virus expression in chronically infected monocytic cells by glutathione, gluthatione ester and $\mathrm{N}$-acetylcysteine. Proc Natl Acad Sci USA 1991; 88: 986-90.

12. Kinscherf R, Fischbach $\mathrm{T}$, Minm S, et al. Effect of glutathione depletion and oral $\mathrm{N}$-acetyl-cysteine treatment on CD4+ and CD8+ cells. FASEB 1994; 1: 448-51.

13. Leeuwenburg C, Ji L. Glutathione and glutathione ethyl ester supplementation of mice alter glutathione homeostasis during exercise. J Nutr 1998 128: $2420-6$.

14. MacKinnon L. Advances in Exercise Immunology. Champaign Illinois, USA: Human Kinetics, 1999: 314-5.

15. McArdle W, Katch F, Katch V. Exercise Physiology. 3rd ed. Philadelphia, USA: Lea and Febiger, 1991: 214-6.

16. Mudd S, Levy $H$, Skovby, F. Disorders of transsulfuration. In: Scriver $C$ Beaudst A, Sly W, Valle D, eds. The Metabolic Basis of Inherited Disease. 7th ed. New York: McGraw-Hill, 1995: 1279-81.

17. Nash L. Can exercise make us immune to disease? The Physician and Sportsmedicine 1986; 14: 251-3.

18. Nieman D. Exercise immunology: Future directions for research related to athletes, nutrition and the elderly. Int J Sports Med 2000; 21: S61-8.

19. Nieman D, Johanssen L, Lee J, Arabatzis K. Infectious episodes in runners before and after the Los Angeles Marathon. J Sports Med Phys Fitness 1990; 30: 316-28.

20. Noakes T. Lore of Running. 3rd ed. Champaign, Illinois: Leisure Press, 1991: 23,49

21. Peters $E$, Bateman E. Ultramarathon running and upper respiratory tract infections - an epidemiological survey. S Afr Med J 1983; 64: 582-4.

22. Peters E, Goetzsche J, Grobbelaar B, Noakes T. Vitamin C supplementation reduces the incidence of post race symptoms of upper respiratory tract infection in ultramarathon runners. Am J Clin Nutr 1993; 57: 170-4.

23. Peters E, Anderson R, Theron A. Attenuation of increase in circulating cortisol and enhancement of the acute phase protein reponse in vitamin C-supplemented ultramarathoners. Int J Sports Med 2001; 22: 120-6.

24. Powers S, Hamilton K. Antioxidants and exercise. Clin Sports Med 1999; 18: 525-36.

25. Reid M, Stokic D, Koch S, Khauli F, Leiss A. N-acetylcysteine inhibits muscle fatigue in humans. J Clin Invest 1994; 94: 2468-74.

26. Roitt I, Brostoff J, Male D. Immunology. 4th ed. London, Mosby, 1996: 6.16.13, 8.1-8.7.

27. Rossouw J, Rossouw F. The effects of lactate-correlated training on running performance: A pilot study. AJPHERD 2000; 6: 38-47.

28. Rowbottom D, Green K. Acute exercise effects on the immune system. Med Sci Sports Exerc 2000; 32: S396-S405.

29. Shephard R, Verde T, Thomas S, Shek P. Physical activity and the immune system. Can J Sports Sci 1991; 16: 163.

30. Snider I, Bazzarre T, Murdoch S, Goldfarb A. Effects of coenzyme athletic performance system as an ergogenic aid on endurance performance to exhaustion. Int J Sport Nutr 1992; 2: 272-86.

31. Stolzenberg-Solomon R, Miller E, Maguire M, Selhub J, Appel L. Association of dietary protein intake and coffee consumption with serum homocysteine concentrations in an older population. Am J Clin Nutr 1999. 69: $467-75$. 
32. Van Brummelen R. L-Methionine: Immune supportive supplement in HIV+ patients: A South African study. Amino Acids 2001; 21: 1-90.

33. Wang S, Chen H, Sheen L, Lii C. Methionine and cysteine affect glutathione level, glutathione-related enzyme activities and the expression of glutathione S-transferase isozymes in rat hepatocytes. J Nutr 1997; 127: 2135-41.
34. Weight L, Myburgh K, Noakes T. Vitamin and mineral supplementation: effect on the running performance of trained athletes. Am J Clin Nutr 1988; 47: 192-5.

35. Weiss C, Kinscherf R, Roth S, et al. Lymphocyte subpopulations and concentrations of soluble CD8 and CD4 antigen after anaerobic training. Int $J$ Sports Med 1995; 16: 117-21. 